\title{
Effectivity of The Combination of Foot Exercises and Hydrotherapy to Peripheral Circulation in Patients Diabetes Mellitus
}

\author{
Rumentalia Sulistini \\ Department of Nursing \\ Politeknik Kesehatan, Ministry of Health \\ Palembang, Indonesia \\ rumentalia@yahoo.com
}

\author{
Azwaldi \\ Department of Nursing \\ Politeknik Kesehatan, Ministry of Health \\ Palembang, Indonesia
}

\begin{abstract}
Diabetes mellitus (DM) is a disease characterized by the body can not regulate blood sugar levels automatically. In Indonesia obtained mortality ulcer/gangrene diabetes ranged between $17-32 \%$ while the amputation rate between $15-30 \%$. Patients died post-amputation was $14.8 \%$, increased to $37 \%$ over three years. The mean age of the patients were only 23.8 months post-amputation. As many as $50 \%$ of amputations in patients with diabetes mellitus is estimated to be preventable if patients are taught preventive measures to treat the foot. Nurses as an important part of nursing caregiver should be able to contribute more in the Prevention of complications in diabetic patients, so we need new interventions to provide care. Aim this study determined the combined effect of foot exercises and hydrotherapy to increase peripheral circulation in patients with DM. The methods this study is an experimental research. The design study is a randomized controlled trial with the pretest-posttest control group. This study was using random sampling. The results are diabetes patients in this experiment consists of male $57.14 \%$, not work $61.9 \%$ and 90.9\%. not have foot ulcers. The average age of the respondents 56.8 years in the intervention group and 59, 5 in the control group. Average 4.33 years longer suffer DM in the intervention group and 59.5 years in the control group with the lowest age at 42 years. Blood sugar levels respondents the average $221 \mathrm{mg} / \mathrm{dL}$ in the intervention group and $180.7 \mathrm{mg} / \mathrm{dl}$ in the control group. There was no difference in mean Ankle Brachial Index (ABPI) in the intervention and control groups. There was a relationship between the value of the long-suffering DM and ABPI.
\end{abstract}

Keywords: diabetes mellitus, foot exercises, hydrotherapy

\section{INTRODUCTION}

Diabetes mellitus (DM) is a disease characterized by the inability of the body regulate blood sugar levels automatically[1]. The prevalence of diabetes mellitus was increasing worldwide every year. Based on WHO (2000) the number of diabetic patients aged over 20 years amounted to 150 million people and is expected to rise until doubled in 2025. Results Health Research[2] obtained the proportion of deaths due to diabetes the productive age group 45-54 years in urban areas ranks second $14.7 \%$ and rural areas DM ranks sixth $5.8 \%$. The incidence of diabetes mellitus in the world $4 \%$ [3]. Diabetes mellitus is a disease that causes the most complications[4]. Complications of diabetes occur all organs in the body. DM also cause disability which affects the quality of life of patients with diabetes mellitus itself. $30 \%$ of patients are blind due to complications of diabetic retinopathy, and $10 \%$ had to undergo amputation of limbs[5]. The research center in Indonesia have rates of death from ulcer or gangrene diabetes ranged between $17-32 \%$, the amputation rate between $15-30 \%$. One year after amputation $14.8 \%$ died, increasing to $37 \%$ in three years. The mean age of the patients only 23.8 months post-amputation[1]. The importance of wound care in patients with Diabetes Mellitus prevent further complications. 50\% of amputations in patients with diabetes mellitus can be prevented if patients are taught preventive measures to treat the foot and put it into practice every day[6]. Nurses as an important part of the nursing caregiver. Nurses should be able to contribute more to the prevention of complications in diabetic patients so that nurses need to perform a variety of research so as to get a new intervention

\section{METHODS}

The design study was a randomized controlled trial with the pretest-posttest control group. Random sampling. Inclusion criteria were age over 17 years, to become respondents signed informed consent. Execution criteria: neurological and musculoskeletal disorders, had wound and difficulty speaking. Criteria for withdrawal: the patient was not willing to continue the treatment, the patient expressed discomfort when intervening. Dropout criteria: patients did not adhere to treatment. Samples were 24 respondents. Researchers used Observation Sheet of Ankle Brachial Index (ABI) before and after the intervention in the treatment group and the comparison group. Analysis this study was using t-test.

\section{RESULTS}

Diabetes patients in this study consisted of male $57.14 \%$, most did not work $61.9 \%$, and $90.9 \%$ did not have foot ulcers. The average age of the respondents 56.8 years in the intervention group and 59, 5 in the control group. Average 4.33 years longer suffer the intervention group and 59.5 in the control group with the lowest age at 42 years. Blood sugar levels respondents the average $221 \mathrm{mg} / \mathrm{dL}$ in the intervention group and $180.7 \mathrm{mg} / \mathrm{dl}$ in the control group. The first day, 
mean ABPI in control group before foot exercises was 0.8 , after foot exercises increased to 0.90 . Overall respondents in the control group did not follow the treatment on the second day, so there wasn't mean ABPI on the second day. Mean ABPI in treatment group before exercises and compress on the first day was 0.93 and after intervention increased 1.07. Of the 14 respondents who follow the treatment until the second day were 8 respondents.

TABLE I. THE MEAN ABPI THE INTERVENTION GROUP IN PRE AND POST COMBINATION EXERCISES AND COMPRESSES $(\mathrm{N}=8)$

\begin{tabular}{cllcc}
\hline Variable & Mean & $\begin{array}{c}\text { Standard } \\
\text { Deviation }\end{array}$ & $\begin{array}{c}\text { Min- } \\
\text { Max }\end{array}$ & $\begin{array}{c}\mathbf{9 5 \%} \\
\text { CI }\end{array}$ \\
\hline ABPI Pre & 0,96 & 0,36 & $0,5-1,5$ & $0,65-1,08$ \\
ABPI Post & 1,03 & 0,26 & $0,6-1,4$ & $0,76-1,29$ \\
& & & & \\
$\begin{array}{c}\text { ABPI Post } \\
\text { second } \\
\text { day }\end{array}$ & 0,94 & 0,16 & $0,7-1,2$ & $0,8-1,07$ \\
\hline
\end{tabular}

TABLE II. THE MEAN DIFFERENCE ABPI PRE AND POS EXERCISES ON CONTROL GROUP

\begin{tabular}{cccccc}
\hline & Mean & SD & SE & p-value & N \\
\hline ABPI Pre & 0,81 & 0,19 & 0,07 & & \\
& & & & 0,11 & 7 \\
ABPI Post & 0,90 & 0,28 & 0,09 & & \\
\hline
\end{tabular}

In Table 2. Mean change of 0.11 and no differences in mean ABPI before and after the leg exercises in the control group $(p>0,05)$. Respondents in the intervention group was given treatment and compress leg exercises on the first day or two. The first day of treatment followed by 15 respondents, then the second day followed by eight respondents. The mean difference ABPI Pre and Post Exercises and compresses the intervention group $(\mathrm{N}=14)$

\begin{tabular}{cccccc}
\hline & Mean & SD & SE & $\begin{array}{c}\text { p- } \\
\text { value }\end{array}$ & N \\
\hline ABPI Pre & 0,963 & 0,36 & 0,12 & 0,609 & 8 \\
& & & & & \\
ABPI Post & 1,024 & 0,26 & 0,09 & & \\
\hline
\end{tabular}

Table 3 shows the mean value changed 0.061 . There were no differences in mean ABPI before and after treatment exercises and compressed $p$-value $=0.609(p>0.05)$

TABLE III. DIFFERENCE MEAN ABPI POST INTERVENTION FIRST DAY AND SECOND DAY

\begin{tabular}{cccccc}
\hline & Mean & SD & SE & $\begin{array}{c}\text { p- } \\
\text { value }\end{array}$ & N \\
\hline $\begin{array}{c}\text { ABPI Post first day } \\
\text { ABPI Post second } \\
\text { day }\end{array}$ & 1,02 & 0,26 & 0,925 & & \\
\hline
\end{tabular}

Table 4 shows the average ABPI first day post intervention was 1.02 with a standard deviation of 0.26 . The second day after intervention mean ABPI decreased to 0.94. analysis showed the $p$-value $=0.356(p>0.05)$. There was no significant difference between the mean ABPI first day and post the second day after the combination exercises and compress in the intervention group

TABLE IV. THE MEAN DIFFERENCE ABPI PRE AND POST INTERVENTION FIRST AND SECOND DAY

\begin{tabular}{cccccc}
\hline & Mean & SD & SE & $\begin{array}{c}\text { p- } \\
\text { value }\end{array}$ & N \\
\hline ABPI Pre H1 & 0,963 & 0,36 & 0,128 & & \\
ABPI Post H2 & 0,941 & 0,05 & 0,058 & & \\
\hline
\end{tabular}

Table 5 shows the average ABPI pre-intervention first day was 0.963 with a standard deviation of 0.36. After the intervention of the Second 0, 941. Statistical analysis showed the $p$-value $=0.821(\mathrm{p}>0.05)$. There were no significant differences between the mean ABPI pre and post a first day and second day after combination the exercises and compress the intervention group.

TABLE V. THE DIFFERENCE MEANS ABPI THE CONTROL GROUP AND INTERVENTION GROUP

\begin{tabular}{cccccc}
\hline & Mean & SD & SE & p-value & N \\
\hline $\begin{array}{c}\text { Intervention group } \\
\text { Control group }\end{array}$ & 1,02 & 0,26 & 0,09 & & 8 \\
& 0,81 & 0,19 & 0,07 & & 7 \\
\hline
\end{tabular}

There is no significant difference between the mean ABPI intervention group and control group $(\mathrm{p}>0,05)$.

TABLE VI. THE DIFFERENCE MEAN ABPI WITH AGE, DURING DM AND BLOOD GLUCOSE $(\mathrm{N}=15)$

\begin{tabular}{ccccc}
\hline Variable & R & R2 & Persamaan Garis & p-value \\
\hline age & 0,374 & 0,140 & $\mathrm{ABPI}=0,191+0,016$ age & 0,170 \\
during DM & 0,526 & 0,276 & $\mathrm{ABPI}=0,904+0,041$ long & $0,044 *$ \\
bloodglucose & 0,405 & 0,164 & $\mathrm{ABPI}=1,32-0,001$ glucose & 0,134
\end{tabular}

no significant relationship between the long suffering from diabetes with ABPI post treatment (p 0.044), so the ABPI will increase 0.904 in case you age 1 year.

\section{DISCUSSION}

The result showed no difference mean Ankle Brachial Pressure Index (ABPI), between the intervention group and control group. In the intervention group of respondents do leg exercises followed by warm compresses and the control group respondents just do leg exercises. But from the results of the study there was no difference in mean ABPI respondents with leg exercises before and after. The result contrast with the statement Kibachio, et al [7] that the regular leg exercises ( $\mathrm{p}$ value 0.018), diet and exercise (p-value 0.004) as well as foot care education ( $p$-value 0.017 ) were a factor related to the occurrence of foot ulcers. The risk of foot ulcers is a risk that can occur in patients with diabetes mellitus. Hydrotherapy is water therapy to improve circulation and blood quality. Alternative therapy using heat and cold are used in the treatment hydrotherapy[8]. This therapy can be used in various situations such as pain and reduces pressure on the foot. To reduce the pressure on the legs and reduces pain treatment is usually done is to soak the foot in warm water for 30 seconds 
and then cold water for 30 seconds, waged repeated for 5 minutes to do 3 or 4 times/day. Ref. [9] states that the foot care can be done by washing feet daily with warm water with a temperature of $32 \mathrm{C}-35 \mathrm{C}$ and exercise helps blood circulation.

The analysis result suffering from Diabetes Mellitus with ABPI after being given exercises and compress the foot indicate a strong relationship ( $\mathrm{r}$ 0.526) patterned positive meaning that the older, the higher the ABPI and there was significant relationship between duration of DM with ABPI post treatment ( $p$ 0.044), so the ABPI 0.904 will increase if there is age 1 year.

\section{CONCLUSION AND RECOMMENDATION}

There were no differences between the mean value ABPI before and after Exercises in the control group. There are no differences between the mean value of ABPI before and after Exercises and compress the intervention group. There are no differences between the mean value of ABPI after Exercises and compress the first day and the second day ( $\mathrm{p}$-value = 0.356). There are no differences between the mean value of ABPI significant between intervention group and control group (p-value 0.107). There is a relationship between the ABPI Old post treatment with diabetes mellitus $(\mathrm{P}=0.044)$.

Further research is needed to examine the combined effects of exercise and compress in a long exercise time at least 4 weeks with a frequency of 2 times a week.

\section{REFERENCES}

[1] D. Antono, "Peran Intervention Perifer pada Kasus Kaki Diabetik," Medistra Hospital, 2015. [Online] Available: http://www.medistra.com/index.php?option=com_content\&view=article \&id=175. [Accessed: 24-May-2016].

[2] Kemenkes, "Kementerian Kesehatan Republik Indonesia," Kemenkes RI, 2013. [Online]. $\quad$ Available: http://www.depkes.go.id/article/view/2383/diabetes-melitus-penyebabkematian-nomor-6-di-dunia-kemenkes-tawarkan-solusi-cerdik-melaluiposbindu.html.

[3] K. Yudianto, H. Rizmadewi, and I. Maryati, "KUALITAS HIDUP PENDERITA DIABETES MELLITUS DI RUMAH SAKIT UMUM DAERAH CIANJUR," Maj. Keperawatan Unpad, vol. 10, no. 18, Apr. 2012.

[4] Misnadiarly, Diabetes mellitus gangren, ulcer, infeksi : mengenali gejala, menanggulangi, mencegah komplikasi. Jakarta: Pustaka Obor, 2006.

[5] K. G. M. M. Alberti, P. Zimmet, and J. Shaw, "International Diabetes Federation: a consensus on Type 2 diabetes prevention," Diabet. Med., vol. 24, no. 5, pp. 451-463, May 2007.

[6] Smetlzer and Bare, Buku Ajar Keperawatan Medikal Bedah Brunner \& Suddarth. Jakarta: EGC, 2002

[7] J. M. Kibachio, J. Omolo, Z. Muriuki, R. Juma, L. Karugu, and Z. Ng 'and ', "Risk factors for diabetic foot ulcers in type 2 diabetes: a casecontrol study, Nyeri, Kenya,” African J. Diabetes Med., vol. 21, no. 20, 2013.

[8] P. Tripathi, R. Srivatava, A. Pandey, R. Pandey, and S. Goswami, "Alternative therapies useful in the management of diabetes: A systematic review," J. Pharm. Bioallied Sci., vol. 3, no. 4, p. 504, Oct. 2011.

[9] W. Sheridan, "PATIENT HANDOUT: Diabetic Foot Care." 